\title{
Women in reproductive science
}

\author{
Marilyn B Renfree \\ School of BioSciences, The University of Melbourne, Melbourne, Victoria, Australia
}

Correspondence should be addressed to M B Renfree; Email: m.renfree@unimelb.edu.au

This paper forms part of a focus section on Women in Reproductive Science. The guest editor for this section was Professor Marilyn Renfree, Ian Potter Chair of Zoology, School of BioSciences, The University of Melbourne, Victoria, Australia

Reproduction (2019) 158 E5-E7

This special issue on women in reproduction acknowledges some of today's female trailblazers in the field of reproduction. When most of these women began their careers, there were few, if any, role models for them to follow. Most reproductive scientists were men; most general practitioners were men; most obstetricians and gynecologists were men. Fortunately, this sex bias has changed today, but due in no small part to the pioneering effort of these and many other women reproductive biologists.

As well as this small representative group who write in this special issue, there were many pioneering women in reproduction who made enormous contributions to the field (Figure 1 and the accompanying Video 1). In the United States, these were Beatrice Mintz who was among the first scientists to produce chimeric and transgenic mammals. Neena B Schwartz's laboratory focused on the factors that establish reproductive cycles in mammals. With her collaborator Cornelia Channing they identified female inhibin (folliculostatin) in follicular fluid, opening up the field of peptide negative feedback regulation. Florence Haseltine has made enormous contributions in the field of women's health and reproductive science. As former director of the Center for Population Research of the National Institute of Child Health and Human Development at the National Institutes of Health, she led the way for advances in contraception research. She founded the Society for the Advancement of Women's Health Research and still strongly supports women in reproduction. At the Jackson Laboratory (colloquially known as the Jax), Eva Eicher was a pioneer in understanding mammalian sex determination with her elegant studies on the $M$. poschiavinus mouse. Hannah Peters and Anne Grete Byskov in Denmark described the development of the germ cells in mouse and human ovary and oocyte biology and the meiosis-activating sterols. In the United Kingdom the most outstanding female reproductive and developmental biologist was Anne McLaren. She was the first woman to hold office - as Foreign Secretary - in the Royal Society and apart from her ground-breaking work on and expertise in mammalian germ cells, she was instrumental in devising the regulations for human embryo experimentation. How much more could we have achieved in our discipline if half of the research population, instead of a fraction, of the reproductive scientists had been women!

\section{Video 1}

The accompanying video introduces this special issue on women in reproduction that acknowledges some of today's female trailblazers in the field of reproduction. Reproduction is a fundamental science that affects all of us, male and female and this issue highlights the innovation and advances made by this representative group of women reproductive scientists. The video (http:// movie-usa.glencoesoftware.com/video/10.1530/REP19-0482/video-1) from the online version of the article is available at https://doi.org/10.1530/REP-19-0482.

There is a common theme running through each of the papers presented here and that is the importance of luck - serendipity - as well as time and place. And despite the real or perceived sex bias, all have had some wonderful and supportive male colleagues. These reviews by this amazing group of women will be an inspiration to young scientists, male and female alike.

Nathalie Josso is the champion of $\mathrm{AMH}$. She details the difficult road from discovery of $\mathrm{AMH}$ and how luck and good management and a long-term collaboration with Jean-Yves Picard led to understanding the functions of $\mathrm{AMH}$ and its receptor. Cloning the elusive $\mathrm{AMH}$ was a race won by a margin by Richard Cate in Pat Donohoe's lab in Boston, but the Josso and Picard team were the leaders in the functional analysis.

Pat Hunt began her career working with the geneticist Pat Jacobs in Hawaii and subsequently, like me, worked with Anne McLaren, who by then was in London. She then joined the Jax lab with Eva Eicher. Pat's research focused on age-related aneuploidy, with great effort ultimately obtaining human oocytes to study the effect of age, showing that there was an age-related increase 

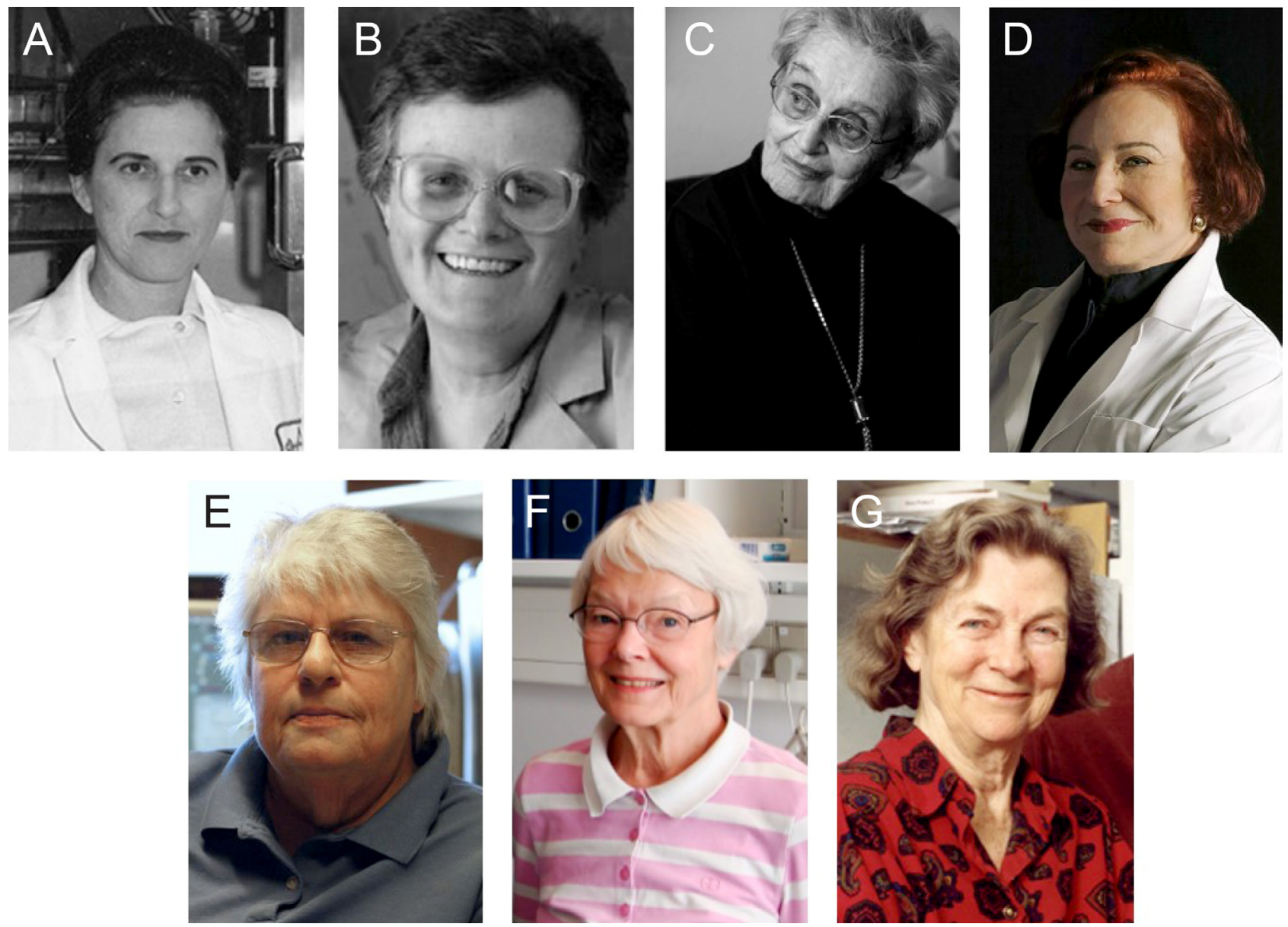

Figure 1 Trailblazers in Reproduction - eminent women scientists who led, or are still leading, the way Professor Beatrice Mintz (A), Professor Neena B Schwartz (B), Professor Hannah Peters (C); Professor Florence Haseltine (D), Dr Eva Eicher (E); Professor Anne Grete Byskov (F) and Dr Anne McLaren. With thanks and permissions from (A) The Smithsonian Institute; (B) Centre for Reproductive Science, Northwestern University, USA; (C) Professor Ken McNatty; (D) Annette Polan; (E) The Jackson Laboratory; (F) Professor Peter Koopman; (G) Wikipedia.

in eggs with spindle aberrations and misaligned chromosomes. But here serendipity once again entered the story and led to a career-altering direction change for Pat. Her mice were inadvertently exposed to bisphenol-A, which resulted in a significant increase in defects in oocytes. The Hunt group discovered that this was due to exposure to this endocrine-disrupting chemical; compounds now known to be ubiquitous in the environment are an increasingly important area of research. This became Pat's central research theme.

Joanne Richards intended to be a teacher but luckily stumbled into research, a $\mathrm{PhD}$ and research in the ovary, ovarian hormones and receptors. Her studies on the LH control of ovulation and cumulus celloocyte complex expansion led to the identification of the complex interactions that control ovulation. This in turn eventually provided the first model of ovarian surface epithelial cancer. Subsequently Joanne's group clarified the importance of normal theca cell function in premature ovarian failure, polycystic ovarian syndrome and ovarian hyperthesosis.
Blanche Capel was an English and Art History Major, not encouraged to continue with her studies by her conservative father. She worked in a gourmet cooking shop after her marriage. By chance she enrolled in a Genetics course, that led to a fellowship in a graduate program just when more women were being recruited. She was lucky to become the first PhD student of Beatrice Mintz. Blanche learnt about stem cells, and since Anne McLaren and Beatrice Mintz were 'arch enemies' her post-doc was instead in the United Kingdom with Robin Lovell-Badge (one of Anne's former research fellows) on homologous recombination in female germ cells during meiosis in the fetal gonad. Working with Robin, she still had the opportunity for interaction with Anne. She was in the right place at the right time, and so became involved in the exciting story of sex determination, a field in which she is now one of the acknowledged leaders.

Lois Salamonsen began her scientific career as a research assistant while following her husband (a clinician) from New Zealand to Melbourne, Bergen and Manchester and back to Melbourne. As a research 
Assistant, Lois was an early developer and user of radioimmunoassay technology; but it was during her $\mathrm{PhD}$ in endometrial protein changes with Jock Findlay that transformed her interest in endometrial function. Understanding infertility, endometriosis, and endometrial cancer became her lifelong research. Her work has contributed significantly to changes in clinical IVF practice, developing a new diagnostic for endometrial receptivity and enhancing endometrial repair.

Teresa Woodruff has spent her career working on the ovarian follicle. Initially she worked on inhibins and activins, but it was the ovarian follicle that was her key focus. She has used a highly innovative and cross-disciplinary approach including material science, chemistry, bioengineering and engineering in her research, to great effect. She developed a successful three-dimensional system for ovarian culture in alginate in vitro. This made follicle maturation in vitro in an artificial ovary possible and provided the answers to many otherwise intractable questions. Then, using inorganic chemistry, she discovered the critical role of zinc fluxes in the process of meiotic maturation, oocytes need zinc to mature.

My work has been almost entirely on marsupials, although I have also worked on women, sheep, elephants and mice! Choosing marsupials was a natural thing for me to do as an Australian, but few others have chosen this group of mammals as their study species of choice because of the difficulties in working with wild animals. Nevertheless, their long post-natal development - they are born in a highly undifferentiated state - has provided some novel and often surprising answers. It has taken a long while for marsupials to be recognized as valuable biomedical models for reproduction and development, and for understanding the evolution of reproduction in mammals.
Future research will use many different model species as it is increasingly recognized that there is no one model that will answer questions about human reproduction. Environmental endocrine disruptors (EEDs) are a pressing problem for reproduction not only in mammals but in most other species and including fish and amphibians. Transgenerational effects of these EEDs are also an increasing concern. Infertility and errors like hypospadias are increasing in men and boys respectively. And as Pat Hunt pointed out, there is the 'dreaded age curve' of older women conceiving affecting the success of conceptions and the viability of embryos.

Reproduction is, after all, a fundamental science that affects all of us, male and female and it is important that we continue to conduct research in both male and female reproduction. As my husband Roger Short always says, 'Reproduction is the science of the transmission of life. What could be more important than that!'.

\section{Declaration of interest}

The author declares that there is no conflict of interest that could be perceived as prejudicing the impartiality of this editorial.

\section{Funding}

This research did not receive any specific grant from any funding agency in the public, commercial or not-for-profit sector.

Received 10 October 2019

First decision 22 October 2019

Accepted 22 October 2019 